\title{
Tricho-dento-osseous syndrome
}

INSERM

\section{Source}

INSERM. (1999). Orphanet: an online rare disease and orphan drug data base. Trichodento-osseous syndrome. ORPHA:3352

Tricho-dento-osseous dysplasia (TDO) belongs to the ectodermal dysplasias and is characterised by curly/kinky hair at birth, enamel hypoplasia with discolouration and molar taurodontism, increased overall bone mineral density (BMD) and increased thickness of the cortical bones of the skull. 